Article

\title{
Routine Production of ${ }^{89} \mathrm{Zr}$ Using an Automated Module
}

A. Lake Wooten ${ }^{1,2}$, Evelyn Madrid ${ }^{1}$, Gordon D. Schweitzer ${ }^{1}$, Luke A. Lawrence ${ }^{1}$, Efrem Mebrahtu ${ }^{1}$, Benjamin C. Lewis ${ }^{1,3}$ and Suzanne E. Lapi ${ }^{1,2, *}$

1 Mallinckrodt Institute of Radiology, Washington University School of Medicine, 660 S. Euclid Ave., St. Louis, MO 63110, USA; E-Mails: lake.wooten.wustl@gmail.com (A.L.W.); madride@mir.wustl.edu (E.M.); gordonschweitzer@gmail.com (G.D.S.); lawrencel@mir.wustl.edu (L.A.L.); mebrahtue@mir.wustl.edu (E.M.); bclewis@wustl.edu (B.C.L.); lapis@mir.wustl.edu (S.E.L.)

2 Department of Biomedical Engineering, Washington University in St. Louis, Campus Box 1097 , 1 Brookings Drive, St. Louis, MO 63130, USA

3 Department of Physics, Washington University in St. Louis, Campus Box 1105, 1 Brookings Drive, St. Louis, MO 63130, USA

* Author to whom correspondence should be addressed; E-Mail: lapis@mir.wustl.edu; Tel.: +1-314-362-4696; Fax: +1-314-362-9940.

Received: 9 May 2013; in revised form: 12 June 2013 / Accepted: 24 June 2013 /

Published: 12 July 2013

Abstract: ${ }^{89} \mathrm{Zr}$ has emerged as a useful radioisotope for targeted molecular imaging via positron emission tomography (PET) in both animal models and humans. This isotope is particularly attractive for cancer research because its half-life $\left(t_{1 / 2}=3.27\right.$ days) is well-suited for in vivo targeting of macromolecules and nanoparticles to cell surface antigens expressed by cancer cells. Furthermore, ${ }^{89} \mathrm{Zr}$ emits a low-energy positron $\left(E_{\beta+\text {,mean }}=0.40 \mathrm{MeV}\right)$, which is favorable for high spatial resolution in PET, with an adequate branching ratio for positron emission $(\mathrm{BR}=23 \%)$. The demand for ${ }^{89} \mathrm{Zr}$ for research purposes is increasing; however, ${ }^{89} \mathrm{Zr}$ also emits significant gamma radiation $\left(\Gamma_{15} \mathrm{keV}=6.6 \mathrm{R} \cdot \mathrm{cm}^{2} / \mathrm{mCi} \cdot \mathrm{h}\right)$, which makes producing large amounts of this isotope by hand unrealistic from a radiation safety standpoint. Fortunately, a straightforward method exists for production of ${ }^{89} \mathrm{Zr}$ by bombarding a natural $\mathrm{Y}$ target in a biomedical cyclotron and then separation of ${ }^{89} \mathrm{Zr}$ from the target material by column chromatography. The chemical separation in this method lends itself to remote processing using an automated module placed inside a hot cell. In this work, we have designed, built and commissioned a module that has performed the 
chemical separation of ${ }^{89} \mathrm{Zr}$ safely and routinely, at activities in excess of $50 \mathrm{mCi}$, with radionuclidic purity $>99.9 \%$ and satisfactory effective specific activity (ESA).

Keywords: ${ }^{89} \mathrm{Zr}$; isotope production; automation; cyclotron; positron emission tomography

\section{Introduction}

The isotope ${ }^{89} \mathrm{Zr}$ is one of several positron-emitting radiometals that are increasing in popularity as radiolabels for positron emission tomography (PET) [1-5]. A search of the PubMed database [6] found over 55 publications with ${ }^{89} \mathrm{Zr}$ mentioned in the title, $75 \%$ of which had been published since 2009 . In particular, ${ }^{89} \mathrm{Zr}$ holds significant potential for immunoPET [4,7-10], a growing technique that uses radiolabelled antibodies, antibody fragments, and peptides for the in vivo molecular imaging of antigens using PET [7,11-14]. ${ }^{89} \mathrm{Zr}$ is well-suited for this technique because it is a positron-emitter with a half-life $\left(t_{1 / 2}=3.27\right.$ days $)$ that is long enough to accommodate the targeting time for these relatively large imaging agents, which is on the order of days. So far, the most prevalent application for ${ }^{89} \mathrm{Zr}$ has been cancer imaging, which is the focus of the majority of publications that used ${ }^{89} \mathrm{Zr}$ for in vivo PET imaging. The information that is obtained using ${ }^{89} \mathrm{Zr}$-immunoPET can be useful for cancer staging, therapy planning, and treatment monitoring, making ${ }^{89} \mathrm{Zr}$ a potentially valuable tool for personalized medicine.

There are several properties of ${ }^{89} \mathrm{Zr}$ that make it an attractive radiolabel for immunoPET. Most importantly, the half-life of ${ }^{89} \mathrm{Zr}$ matches the biological half-life of antibodies. Additionally, ${ }^{89} \mathrm{Zr}$ emits positrons with a sufficient branching ratio $(y=23 \%)$ and provides good PET spatial resolution because it emits positrons at a low average energy $\left(E_{\beta+, a v g}=396 \mathrm{keV}\right)$, and therefore a lower positron range (1.2 mm [15]) compared to several other PET isotopes. Unfortunately, ${ }^{89} \mathrm{Zr}$ also emits a high energy (909 keV) gamma ray with a high branching ratio $(99.0 \%)$. Thus, ${ }^{89} \mathrm{Zr}$ has a high gamma factor, $\Gamma_{15 \mathrm{keV}}=6.6 \mathrm{R} \cdot \mathrm{cm}^{2} \cdot \mathrm{mCi}^{-1} \cdot \mathrm{h}^{-1}$ (weighted average of all gamma rays emitted) [16], meaning that the dose rate for this isotope is significant. The $\mathrm{Zr}^{4+}$ ion prefers a coordination state of 6 to form a stable complex, and, so far, the most prevalent chelator of ${ }^{89} \mathrm{Zr}$ is desferrioxamine (DFO) $[8,17]$. Table 1 summarizes chemical and nuclear decay properties of ${ }^{89} \mathrm{Zr}$, including a simplified decay scheme.

The vast majority of medical centers capable of producing medical isotopes do so using a low-energy "biomedical" cyclotron capable of bombarding a target with protons with energy $\left(E_{p}\right)<20 \mathrm{MeV}$ (and alternatively deuterons with energy $\left(E_{d}\right)<10 \mathrm{MeV}$ ). For these particles and energies, the highest cross-section is the $(p, n)$ reaction with a peak cross-section of $\sim 0.8 \mathrm{~b}$ at $E_{p} \sim 14 \mathrm{MeV}$. The $(p, n)$ reaction uses ${ }^{89} \mathrm{Y}$ target material, which is $100 \%$ naturally abundant and thus relatively inexpensive. For the above reasons, the ${ }^{\text {nat }} \mathrm{Y}(p, n)^{89} \mathrm{Zr}$ reaction is the most common reaction route for ${ }^{89} \mathrm{Zr}$ production [18]. However, contaminants can also be produced in a ${ }^{\text {nat }} Y$ foil via the following common low-energy positron reactions: $(p, n)^{89 \mathrm{~m}} \mathrm{Zr},(p, 2 n)^{88} \mathrm{Zr},(p, p n)^{88} \mathrm{Y}$, as shown in the Electronic Supplementary Information (ESI). Fortunately, high radionuclidic purity can still be achieved using $\sim 15 \mathrm{MeV}$ protons because ${ }^{89 \mathrm{~m}} \mathrm{Zr}$ has a short half-life $\left(t_{1 / 2}=4.2 \mathrm{~m}\right)$ and a high degree of isomeric transition $(\mathrm{IT}=93.8 \%$ ) and because the $(p, 2 n)$ and $(p, p n)$ reactions require greater proton beam energies, so they have low cross-sections at $E_{p} \sim 15 \mathrm{MeV}$-less than 0.2 and $0.02 \mathrm{~b}$, respectively [19]. The important 
characteristics of ${ }^{89} \mathrm{Zr}$ production in general are summarized in Table 2, and the parameters and results from eight publications [20-27] about ${ }^{89} \mathrm{Zr}$ production are shown in the ESI.

Table 1. Summary of chemical and nuclear decay properties of ${ }^{89} \mathrm{Zr}$ with a simplified decay scheme.

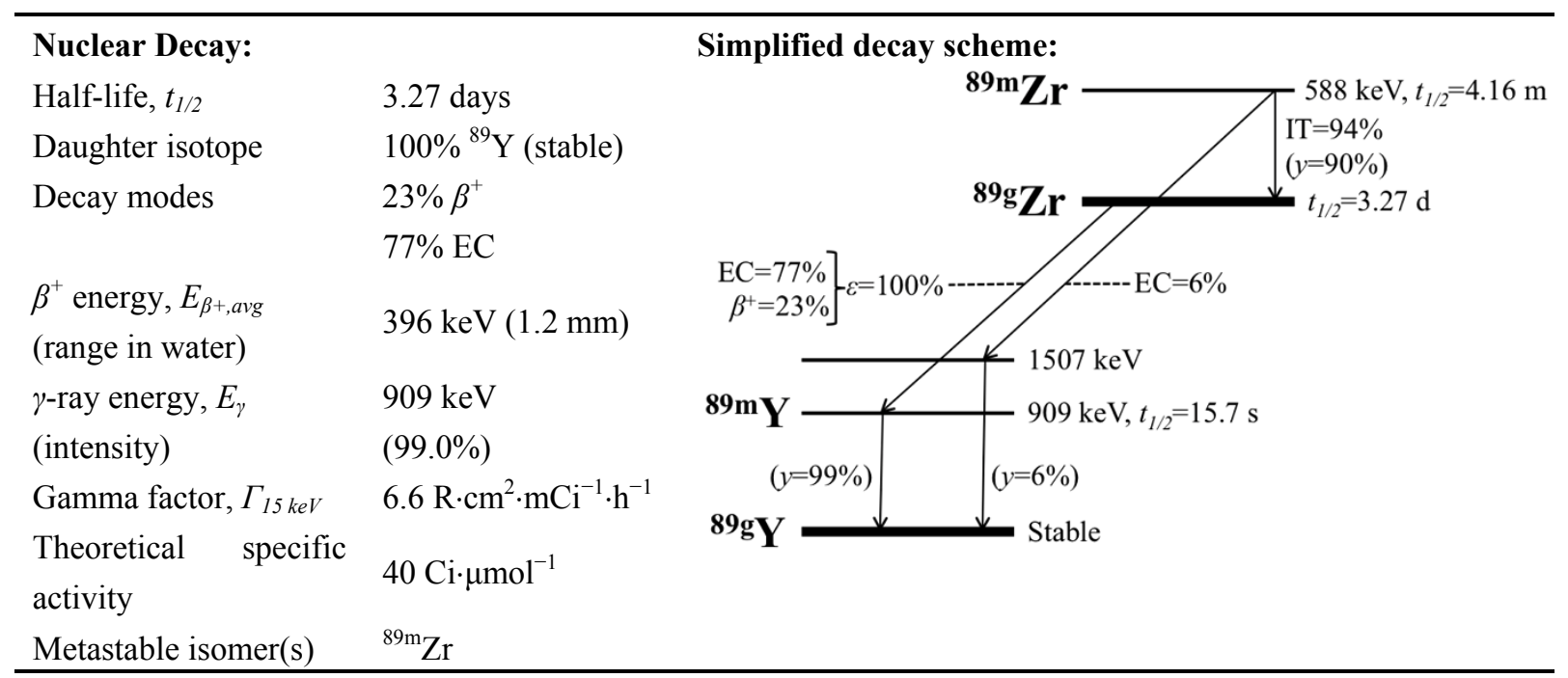

The gamma factor in the table accounts for gamma ray energies $\geq 15 \mathrm{keV}$. The decay scheme displays all gamma-rays with intensity $(y)>1 \%$. Percentages indicate the overall intensity of each transition. DFO: desferrioxamine; EC: electron capture; IT: isomeric transition; $\beta^{+}$: positron emission; $\gamma$ : gamma-ray; $\varepsilon$ : $\mathrm{EC}+\beta^{+}$transition $[15,16,19,23]$.

Table 2. Summary of characteristics for production of ${ }^{89} \mathrm{Zr}$ using a low-energy, biomedical cyclotron.

\begin{tabular}{ll}
\hline Target (natural abundance) & ${ }^{\text {nat }} \mathrm{Y}\left(100 \%{ }^{89} \mathrm{Y}\right)$ \\
Production reaction & $(p, n)^{89} \mathrm{Zr}\left(t_{1 / 2}=3.27\right.$ days $)$ \\
Peak cross-section and energy, $\sigma\left(E_{\beta+}\right)$ & $\sim 0.8 \mathrm{~b}(\sim 15 \mathrm{MeV})$ \\
Reaction threshold, $Q$ & $3.7 \mathrm{MeV}$ \\
Stopping range of $14.7 \mathrm{MeV}$ protons & $1.02 \mathrm{~mm}$ \\
Other possible reactions & $(p, n)^{89 \mathrm{~m}} \mathrm{Zr}\left(t_{1 / 2}=4.2 \mathrm{~m}\right)$ \\
& $(p, 2 \mathrm{n})^{88} \mathrm{Zr}\left(t_{1 / 2}=83.4\right.$ days $)$ \\
& $(p, p n)^{88} \mathrm{Y}\left(t_{1 / 2}=107\right.$ days $)$ \\
Optimum beam energy, $E_{p}$ & $13 \mathrm{MeV}$ \\
Target preparation & hot-rolled ${ }^{\text {nat }} \mathrm{Y}$ metal foil \\
\hline
\end{tabular}

Optimum beam energy was selected to avoid production of ${ }^{88} \mathrm{Zr}$ contaminant, while still producing ${ }^{89} \mathrm{Zr}[19,28-36]$.

Out of eight papers that used the $(p, n)$ reaction for ${ }^{89} \mathrm{Zr}$ production, five used $\mathrm{Y}$ foil targets [20,21,23,26,27], two used sputtered $\mathrm{Y}$ onto $\mathrm{Cu}$ [24,25], and one used $\mathrm{Y}_{2} \mathrm{O}_{3}$ pellets [22]. Although the sputtered targets provided superior heat transfer and therefore allowed for higher beam currents, we chose to use $\mathrm{Y}$ foil for ease of use. For a hypothetical irradiated $\mathrm{Y}$ foil that contains $100 \mathrm{mCi}$ of ${ }^{89} \mathrm{Zr},<0.3 \mu \mathrm{g}$ of ${ }^{89} \mathrm{Zr}$ atoms are present in the foil, and these product atoms must be extracted chemically to give the desired product - a solution containing ${ }^{89} \mathrm{Zr}^{4+}$ ions. This separation has been performed with mixed results using several different techniques [23], including solvent extraction [21,22,26,27,37], solid cation exchange [21,22], solid anion exchange [22,26,27,38], and 
solid hydroxamate resin [23-25,39,40]. Hydroxamate resin separation has emerged as the preferred method following the publication of a standardized method for producing and separating ${ }^{89} \mathrm{Zr}$ by Holland, et al. [23]. This separation can produce high recovery, radionuclidic purity, and effective specific activity (ESA). Our work does not contribute new separation chemistry; rather, the objective for this work was to automate the process that was reported by Holland, et al. [23] based on chemistry that was developed by Verel, et al. [24], Meijs, et al. [25], and Herscheid, et al. [39].

Automation is an important part of isotope production in particular and nuclear medicine in general because automated modules enable production centers to separate large activities of isotopes while still meeting institutional and federal regulations for radiation dose. Automated modules are ubiquitous at many PET centers, where they are typically used in good manufacturing practice (GMP) facilities for synthesizing patient doses of radiopharmaceuticals, such as $\left[{ }^{18} \mathrm{~F}\right]$ fluoro-deoxy-glucose $\left(\left[{ }^{18} \mathrm{~F}\right] \mathrm{FDG}\right)$. Automated modules are essential to such processes because these syntheses are for human injection and because the radiolabels for these compounds have short half-lives, high activities, and high gamma factors. Therefore, automated modules are used to make the synthesis clean, reproducible, fast, and safe to production personnel. Although most PET radiometals are still at the research stage, automated separation modules are still useful for many of the same reasons, but principally to minimize dose to personnel. Several groups have published on custom-made automated modules for various radiometals, including ${ }^{64} \mathrm{Cu}$ [41-44], ${ }^{124} \mathrm{I}[45],{ }^{99 \mathrm{~m}} \mathrm{Tc}$ [46], ${ }^{86} \mathrm{Y}$ [47], and ${ }^{89} \mathrm{Zr}[48,49]$. In this work, we have designed, built and commissioned a module that has performed the chemical separation of ${ }^{89} \mathrm{Zr}$ safely and routinely, at activities in excess of $50 \mathrm{mCi}$, with high radionuclidic purity and satisfactory ESA.

\section{Experimental Section}

\subsection{Materials}

${ }^{\text {nat }}$ Y foil (99.9\% purity) was purchased from Alfa Aesar (Ward Hill, MA, USA), and Nb metal $\mathbf{( 9 9 . 8 \% )}$ was purchased in rod form from A.D. Mackay (Denver, NC, USA). A silica-based weak cation exchange resin was purchased from Waters (Milford, MA, USA). Trace metals grade water purchased from Sigma-Aldrich (St. Louis, MO, USA) was used for all liquids in the automated chemical separations. Ultrapure $(\sim 18 \mathrm{M} \Omega)$ water was purified in a Millipore system (Billerica, MA, USA) and was used for all other purposes, including cleaning the automated module before each use and making solutions for DFO titrations. DFO-NCS was purchased from Macrocyclics (Dallas, TX, USA), and all other chemicals were purchased from Sigma-Aldrich.

\subsection{Cyclotron Production}

Discs with diameter $9.5 \mathrm{~mm}$ were punched from $0.64 \mathrm{~mm}$ thick ${ }^{\text {nat }} \mathrm{Y}$ foil (disc mass $\sim 0.2 \mathrm{~g}$ ). $\mathrm{Nb}$ metal target holders were machined, consisting of a base and a screw-on lid with a centered, circular hole to expose the target foil to the cyclotron beam. $\mathrm{Nb}$ was selected because of its high melting temperature $\left(T_{m}=2,468{ }^{\circ} \mathrm{C}\right)$ and high chemical inertness [50]. A single ${ }^{\text {nat }} \mathrm{Y}$ disc was placed inside the target holder, as shown in Figure 1. Due to activation, many target holders were machined to allow residual activity to decay before reuse. Before each target holder was reused, it was scrubbed by hand 
using a cotton swab dipped in a slurry made from $\mathrm{Al}_{2} \mathrm{O}_{3}$ powder and water, if deemed necessary. The target holder was placed in $6 \mathrm{M} \mathrm{HCl}$ for $1-4 \mathrm{~h}$ for cleaning and dried in an oven. The target assembly was mounted in the CS-15 cyclotron (The Cyclotron Corporation, Berkeley, CA, USA) at the Mallinckrodt Institute of Radiology (MIR) and bombarded with protons ( $E_{p} \approx 14.7 \mathrm{MeV}$ ) to produce ${ }^{89} \mathrm{Zr}$ via the ${ }^{\mathrm{nat}} \mathrm{Y}(\mathrm{p}, \mathrm{n}){ }^{89} \mathrm{Zr}$ reaction. The beam exit energy was $E_{p} \approx 7.9 \mathrm{MeV}$, based on calculations performed using The Stopping Range of Ions in Matter (SRIM) software [28], which implements the Bethe formula for stopping power. After $E_{p}$ was degraded by the $\mathrm{Y}$ foil, the beam stopped in the base of the $\mathrm{Nb}$ target holder, as calculated with Transport of Ions in Matter (TRIM) module within the SRIM package (see ESI). During bombardment, the target holder assembly was cooled on the beam side by a $\mathrm{He}$ gas jet and on the reverse side by flowing chilled water $\left(T \approx 2.2{ }^{\circ} \mathrm{C}\right)$. Following irradiation, the target remained in the solid target station for a few hours to allow for the decay of short-lived contaminants, especially ${ }^{89 \mathrm{~m}} \mathrm{Zr}$ in the $\mathrm{Y}$ foil. Then, the target assembly was removed by hand, and other short-lived contaminants were allowed to decay overnight while the target was in a shielded location. On the following morning, chemical separation was performed in the hot cell that contained the automated module.

Figure 1. Photograph of the disassembled (left) and assembled (right) $\mathrm{Y}$ foil target and $\mathrm{Nb}$ target holder.
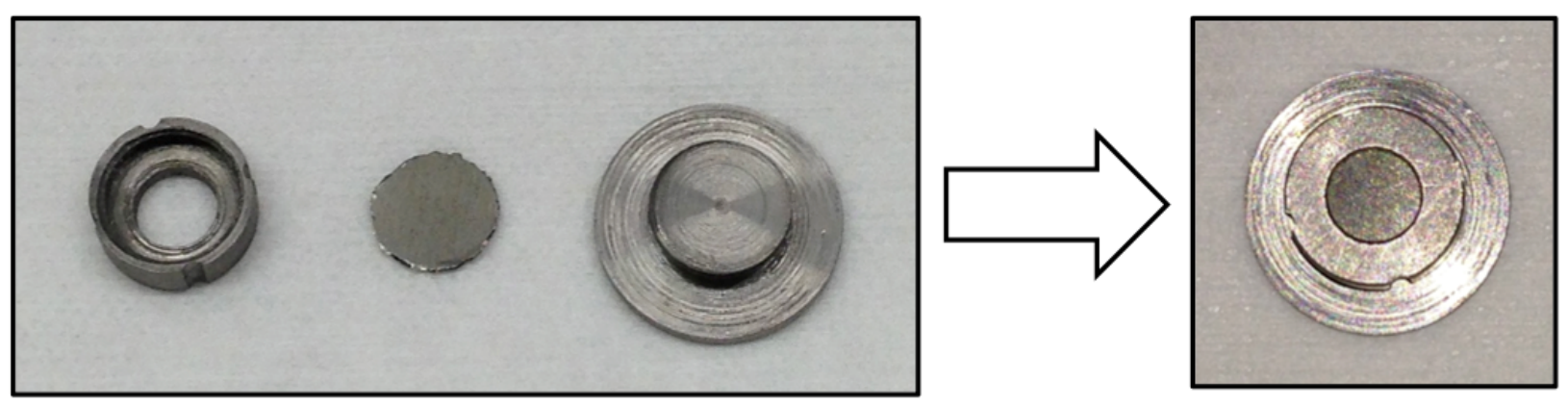

\subsection{Separation Chemistry}

Figure 2 summarizes the general steps in our production process. A stock of hydroxamate resin was made by functionalizing the weak cation exchange resin with hydroxamate groups according to a procedure published in Holland, et al. [23], based on chemistry developed by others [24,25,39]. Chemical separation of ${ }^{89} \mathrm{Zr}$ from the ${ }^{\text {nat }} \mathrm{Y}$ foil was performed in an in-house built automated module installed inside a lead hot cell (Comecer, Castel Bolognese, Italy), typically on the day after bombardment. During setup for each separation of ${ }^{89} \mathrm{Zr}, 100 \mathrm{mg}$ of hydroxamate resin from this stock was loaded between two polyethylene (PE) frits (Grace, Deerfield, IL, USA), which were between two small pieces of glass wool, and loaded into a custom-blown glass column reservoir that was then incorporated into the system with air-tight connections. The entire irradiated target assembly-target holder and target foil-was quickly dropped into a Teflon dissolution vessel mounted on the automated system. This transfer was performed manually, the door to the hot cell was then closed, and the remaining steps in the purification process were performed remotely. Work is underway on a system that will automate the transfer of the target from a custom-made transport safe to the dissolution vessel in the automated module. 
Figure 2. (A) A flowchart describing the process for production and chemical separation of ${ }^{89} \mathrm{Zr}$ from an irradiated $\mathrm{Y}$ foil. Bold text indicates automated steps; dashed line, steps that are currently performed manually; (B) A photograph of the automated module.
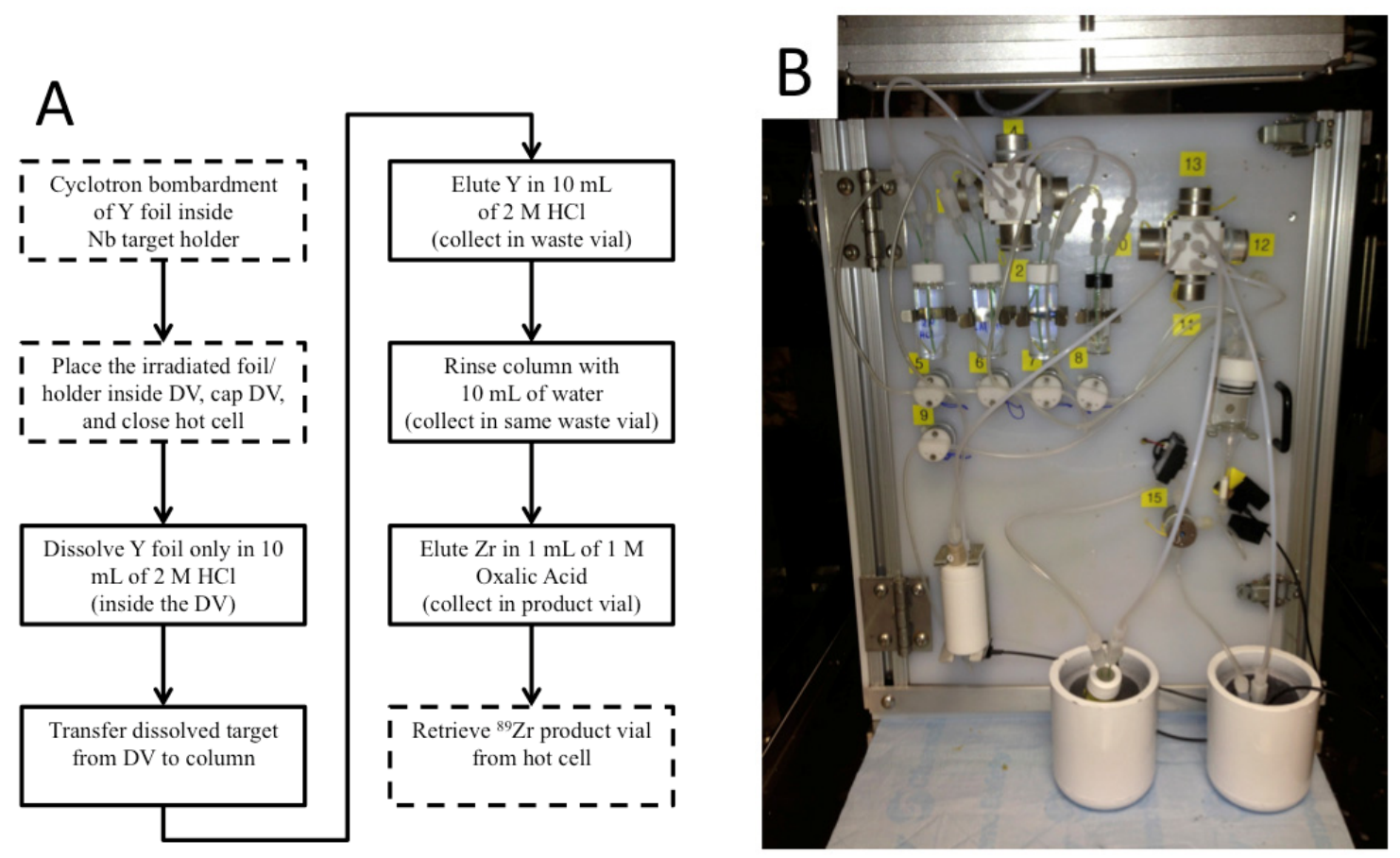

Using a custom software program made in LabVIEW (National Instruments, Austin, TX, USA) running on a laptop outside the hot cell (see Section 2.4), $10 \mathrm{~mL} 2 \mathrm{M} \mathrm{HCl}$ was added to the dissolution vessel to dissolve the ${ }^{\text {nat }} \mathrm{Y}$ target. After waiting $\sim 1 \mathrm{~h}$ for complete dissolution, the dissolved target was transferred to the column through tubing using compressed air. Then, the $\mathrm{Y}$ was eluted from the column in $10 \mathrm{~mL} 2 \mathrm{M} \mathrm{HCl}$ and collected in a waste vial, leaving the ${ }^{89} \mathrm{Zr}$ bound on the column. The column was rinsed with $10 \mathrm{~mL}$ water, which was collected in the same waste vial, and then the ${ }^{89} \mathrm{Zr}$ was eluted in $1 \mathrm{~mL} 1 \mathrm{M}$ oxalic acid and collected in a product vial as ${ }^{89} \mathrm{Zr}$ chelated by the oxalate ions ( ${ }^{89} \mathrm{Zr}$-oxalate). Although other studies have achieved greater recovery and activity per volume by collecting multiple fractions from the column [23-25], we currently have automated the collection for only one elution of the product for simplicity in the automated module. However, to compensate for collecting a single fraction, we increased slightly the volume of eluent to $1 \mathrm{~mL}$. After collection of ${ }^{89} \mathrm{Zr}$ in the product vial, the product was retrieved from the hot cell manually and then dispensed in $2 \mathrm{~mL}$ skirted microcentifuge tubes for distribution within our institution and/or shipping to extramural researchers.

\subsection{Automated Module}

An automated module was designed and built to perform $\mathrm{Zr}-\mathrm{Y}$ separation protocol remotely inside a lead hot cell. The frame for this module $(h \times w \times d=21 \times 18 \times 11$ in. $=0.53 \times 0.46 \times 0.28 \mathrm{~m})$ was constructed of extruded Al modular framing, to which walls were attached that were made of ultra high-molecular weight polyethylene. Various system components were mounted on these plastic walls, as pictured in Figure 2. The front panel of the module was hinged to allow easy access to the components and wiring inside the module. All liquids were pushed through the system by 
compressed air through C-Flex ${ }^{\circledR}$ flexible tubing and through needles made of polyetheretherketone $\left(\mathrm{PEEK}^{\mathrm{TM}}\right.$ ) tubing. The compressed air was delivered to various parts of the system through polytetrafluoroethylene (PTFE) tubing. All liquid and most gas connections were assembled using non-metallic connectors, which reduced exposure to metals that may have compromised ESA. Many of the liquid connection pieces were designed for high pressure liquid chromatography (HPLC) systems and were made of ethylene-tetrafluoroethylene (ETFE, Tefzel ${ }^{\circledR}$ ); gas connections were made using stainless steel Swagelok ${ }^{\circledR}$ tube fittings (Swagelok, Solon, OH, USA). The path of fluids (liquids and air) through the system was controlled by solenoid-actuated isolation valves, and, as a fail-safe, solenoid-actuated pinch valves prevented liquids from flowing through the flexible tubing at inappropriate times or in the opposite direction. Solenoid valves were manufactured by NResearch (West Caldwell, NJ, USA). Solvents only came in contact with polymers and glass in the system. The compressed air was adjusted by a pressure regulator (Swagelok). The flow of compressed air was precisely controlled by a hot wire anemometer mass flow controller (Pneutronics) that received commands from the computer. Before each separation, all liquid solvents were pre-loaded into the system by hand in glass vials capped with silicone rubber septa that allowed for insertion of two PEEK needles - one connected to compressed air and one for transporting the liquid. The vials were then clipped onto the front of the module, and during the separation each liquid was extracted from its vial using positive pressure from the PEEK needle that was connected to compressed air. The general schematic of the entire system is shown in Figure 3.

Figure 3. Process flow diagram for the automated module used for chemical separation of ${ }^{89} \mathrm{Zr}$ from irradiated $\mathrm{Y}$ foils. CAP: compressed air pump; $\mathrm{CV}$ : check valve; $\mathrm{HV}$ : hand valve; MFC: mass flow controller; NC: normally closed; NO: normally open; R: radiation detector; RV: regulator valve; SI: solenoid isolation; SP: solenoid pinch; V: valve; VP: Venturi pump; double line: PTFE tubing for compressed air or vented air only; solid line: flexible tubing for liquids and compressed air. Valves enclosed by a dashed box are part of a gradient manifold. Valves V14, V18, and V19 do not exist in the actual system, so they are not displayed here. (Illustration made using Edraw Max software [51]).

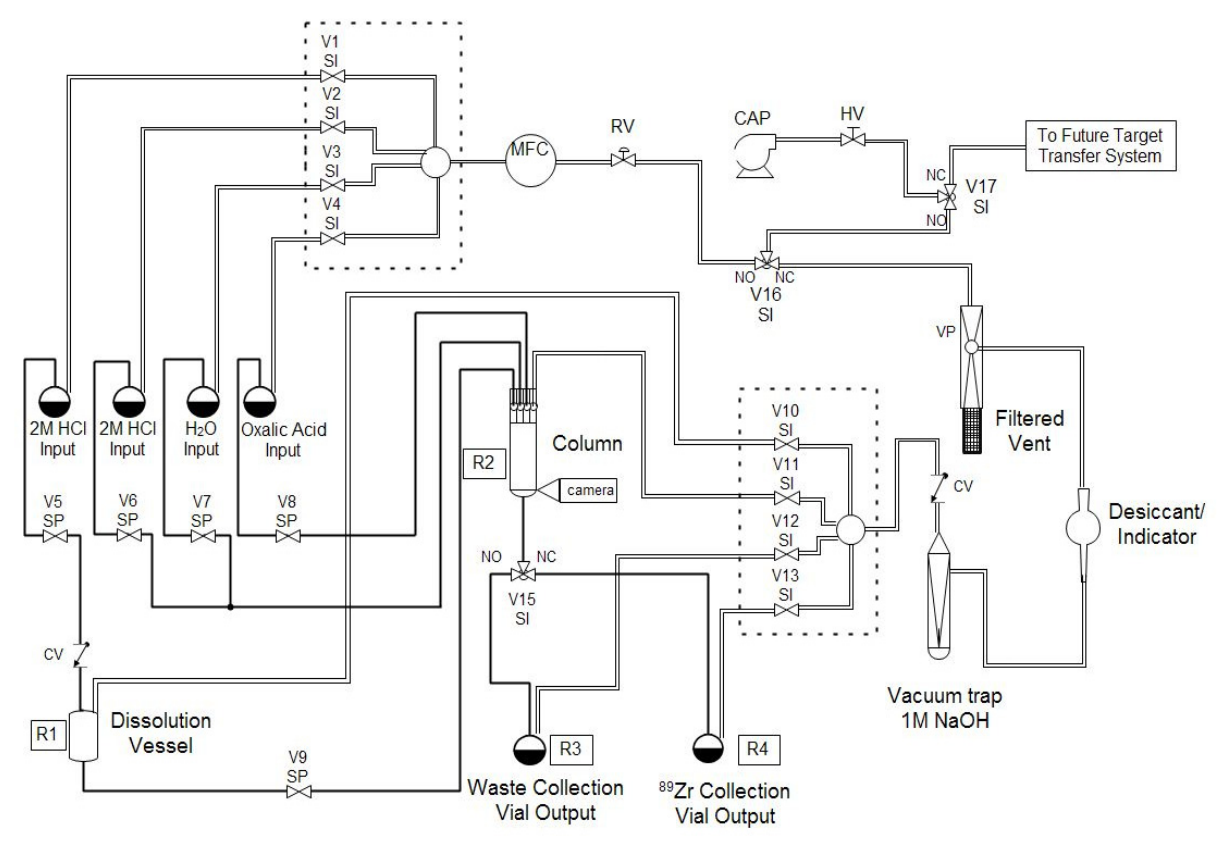


A computer located outside of the hot cell was used to control the entire chemical separation process. A program was created on the LabVIEW platform that featured a graphical user interface (GUI) that provides instructions and controls for production personnel. Users could follow a step-by-step procedure with a pre-programmed control scheme and, if necessary, intervene by controlling individual valves in the event of a problem in the system. Using the GUI, the user can easily and precisely change the flow through the mass flow controller and thereby the speed at which liquids were pushed through the system, most importantly the speed of solvents through the column. We found that to improve recovery, the final eluent was allowed to sit on the column for $\sim 20 \mathrm{~min}$. and then slowly pushed through the column at $\sim 0.2-1 \mathrm{~mL} / \mathrm{min}$. The GUI also included a live video feed from a mini color camera (ApexCCTV, Allen, TX, USA) providing an up-close view of the liquid on the column, as well as real-time graphs that reported the radiation dose measured by four Si PIN-type photodiode detectors (Carroll \& Ramsey, Berkeley, CA, USA). These detectors were strategically placed close to the dissolution vessel, resin column, waste vial, and product vial (see Figure 3), allowing the user to monitor the movement of radioactivity through the system in real time. A screenshot of the GUI near the end of a separation process is shown in Figure 4.

Figure 4. Screenshot of the window containing the graphical user interface (GUI) that was used to control the automated module. This image was captured near the end of the separation process. Notice that the time scales for the bottom three graphs match each other but differ from the graph for the dissolution vessel (DV) as it begins to collect data earlier in the procedure.

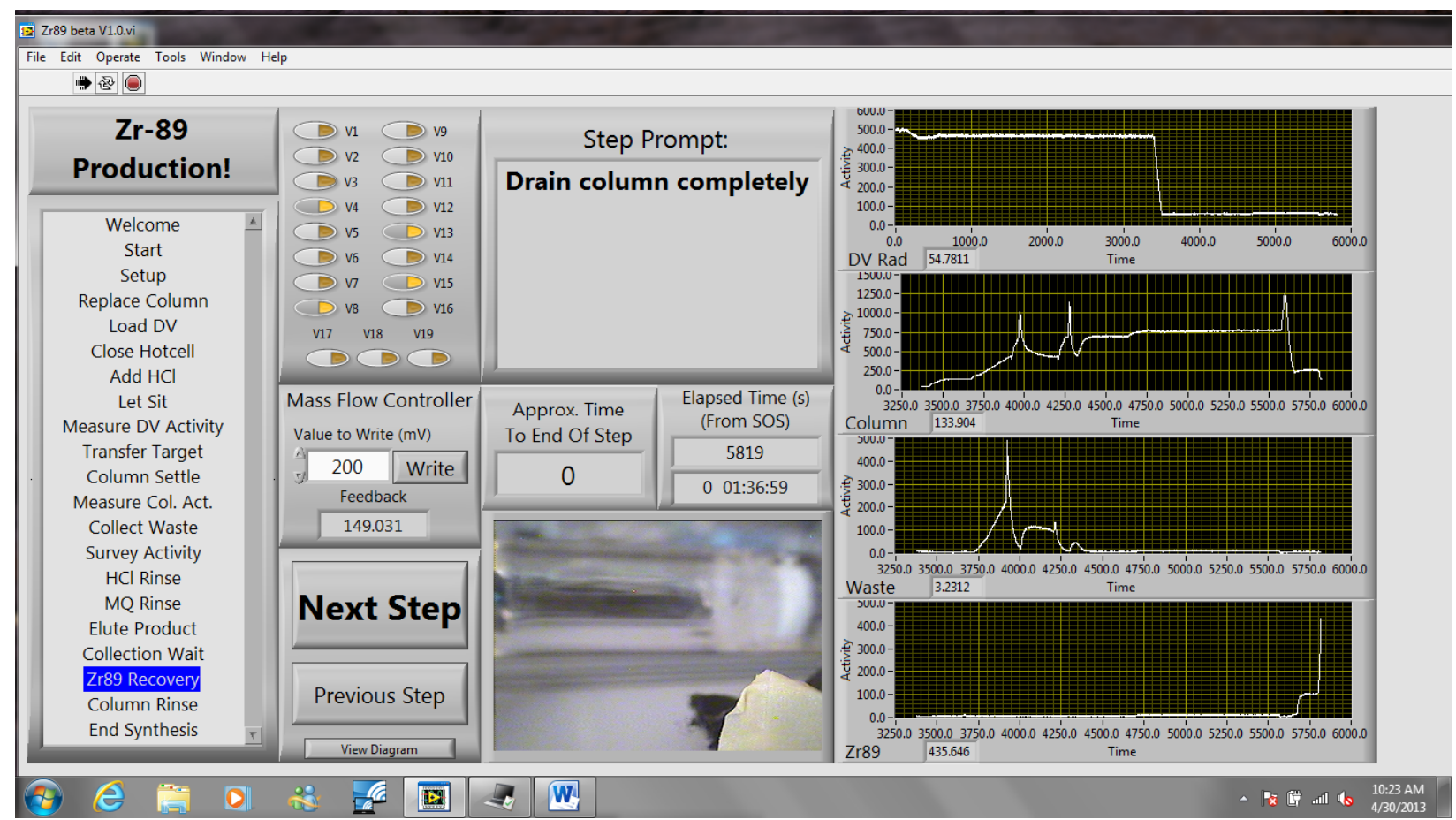

\subsection{Product Characterization}

The final product was characterized for activity amount, radionuclidic purity, and ESA. The amount of activity that was recovered was measured using a dose calibrator (Capintec, Ramsey, NJ, USA) 
using a dial setting of 465 . The radionuclidic purity was characterized using a high-purity Ge detector (Canberra, Meriden, CT, USA) connected to a digital spectrum analyzer (Canberra). The product was diluted in $2 \mathrm{~mL}$ skirted microcentrifuge tubes, and a $10 \mathrm{~m}$ scan of the product was performed within one half-life of the original bombardment. To search for longer-lived contaminants, an aliquot of one production was allowed to decay for $\sim 3$ half-lives and then scanned for $12 \mathrm{~h}$. Gamma ray peaks were identified based on characteristic gamma-rays, which are summarized in Table S2. DFO titration was used to determine ESA - the activity per total amount of metals - as per Holland, et al. [23]. To minimize non-specific binding of other metals by the DFO, the DFO was challenged by $50 \mathrm{mM}$ DTPA. The titration was carried out by thin layer chromatography (TLC) on pure cellulose blotting paper that was developed in $50 \mathrm{mM}$ DTPA and scanned using a radio-TLC imaging scanner (Bioscan, Washington, DC, USA).

\section{Results and Discussion}

The methods described in this work have been used successfully for several months for the cyclotron production and chemical separation of ${ }^{89} \mathrm{Zr}$. Typically, after the chemical separation was completed using the automated module, a dose calibrator was used to measure the activity of ${ }^{89} \mathrm{Zr}$ collected in the product and waste vials. To reduce radiation dose, the system was allowed to decay for one week before measuring the dissolution vessel, which still contained the irradiated $\mathrm{Nb}$ target holder, and the intact column assembly, which still included the resin, frits, and glass wool. The radioactivity measured for all four major module components was decay-corrected to the end-of-bombardment (EOB) time for each production. The decay-corrected activities were summed to give an estimated total radioactivity of ${ }^{89} \mathrm{Zr}$ produced in each cyclotron bombardment. This estimate neglects any activity that was lost in tubing, valves, etc., but it allows us to compare the performance of the automated chemical separation for productions with different starting activities. The majority $(74 \% \pm 16 \%)$ of ${ }^{89} \mathrm{Zr}$ was collected in the product vial and the largest loss of activity was to the column $(18 \% \pm 15 \%)$, which was greater than either the waste vial $(4 \% \pm 10 \%)$ or the dissolution vessel $(3 \% \pm 3 \%)$, as shown in Figure 5. The percentage of ${ }^{89} \mathrm{Zr}$ activity collected in the product vial is the recovery rate of the chemical separation that was carried out using the automated module and is an important performance indicator for the separation process. Our average recovery was significantly lower than other publications about ${ }^{89} \mathrm{Zr}$ production (see ESI). In some cases this may be a result of us only collecting one elution instead of multiple fractions; otherwise, it may be because the stock of hydroxamate resin became less effective at binding $\mathrm{Zr}$ if it was stored for too long. We chose to make a stock of the resin for simplicity to avoid functionalizing a new batch of resin for each production.

Characteristics for ten selected productions are shown in Table 3, including cyclotron parameters, predicted and estimated yields from the cyclotron, and ESA. All targets were bombarded with $\sim 14.7 \mathrm{MeV}$ protons. In this current work, $\mathrm{Nb}$ was selected as the material for the target holder primarily because of its chemical inertness toward $\mathrm{HCl}$ and its high melting temperature. The $\mathrm{Nb}$ target holders have been irradiated up to $15 \mu \mathrm{A}$ without significant alterations of target or target holder. Since the same beam current, beam energy, and foil thickness were used for all productions in this work, the bombardment time $(t)$ was the only bombardment parameter that was adjusted to control the amount of activity produced in the cyclotron. The maximum bombardment time in this work was $4 \mathrm{~h}$, which was 
equivalent to $60 \mu \mathrm{A} \cdot \mathrm{h}$. The parameters for comparable publications varied widely. Excluding the $\mathrm{Y}_{2} \mathrm{O}_{3}$ pellet targets, only one publication [26] used a foil that was close to ours in thickness. Also, the beam current, bombardment time, and $\mu \mathrm{A} \cdot \mathrm{h}$ all varied widely across publications. Not surprisingly, the $\mathrm{Y}_{2} \mathrm{O}_{3}$ targets used lower currents, presumably because of reduced heat transfer, while the sputtered targets received high beam current for long bombardment times.

Figure 5. Distribution of ${ }^{89} \mathrm{Zr}$ in various components after each production. For each production, the activity in each of the four primary system components was decay-corrected to a common time point (end-of-bombardment in the cyclotron) and calculated as a percentage of the total activity. Displayed here are the average percentages for each component $\pm 1 \sigma . N=14$.

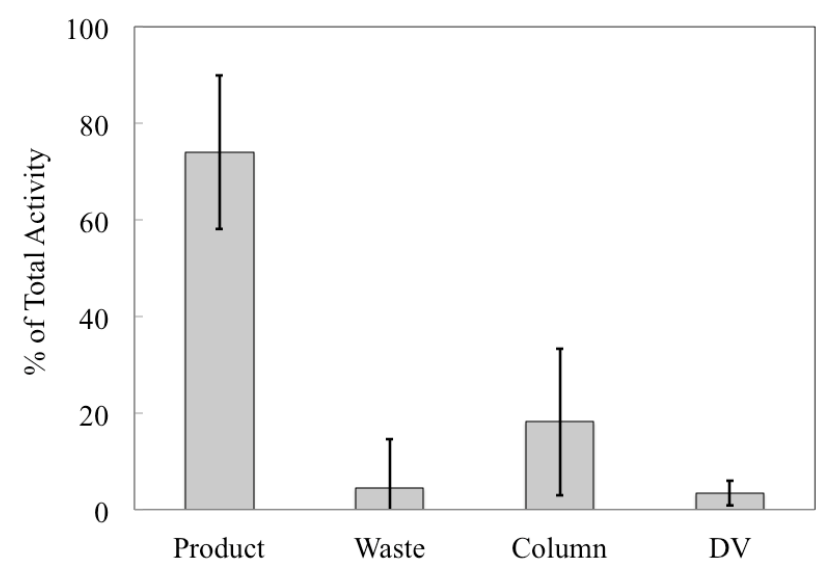

Table 3. Results from ten productions of ${ }^{89} \mathrm{Zr}$ selected for having the highest effective specific activities (sorted from highest to lowest).

\begin{tabular}{|c|c|c|c|}
\hline $\begin{array}{c}\text { Bombardment } \\
\text { Time } \\
\text { h }(\boldsymbol{\mu A} \cdot \mathbf{h})\end{array}$ & $\begin{array}{c}\text { Predicted Activity } \\
\text { from Cyclotron } \\
\text { mCi }\end{array}$ & $\begin{array}{c}\text { Estimated Total } \\
\text { Activity } \\
\text { mCi } \\
\text { (\% of Predicted) }\end{array}$ & 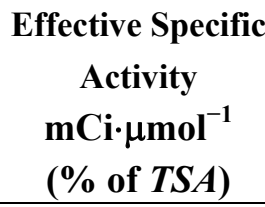 \\
\hline $4(60)$ & 79 & $62(78 \%)$ & $353(0.88 \%)$ \\
\hline $2(30)$ & 40 & $30(74 \%)$ & $250(0.63 \%)$ \\
\hline $2(30)$ & 40 & $30(76 \%)$ & $134(0.33 \%)$ \\
\hline $2(30)$ & 40 & $29(74 \%)$ & $87(0.22 \%)$ \\
\hline $2(30)$ & 40 & $27(68 \%)$ & $73(0.18 \%)$ \\
\hline $2(30)$ & 40 & $30(75 \%)$ & $63(0.16 \%)$ \\
\hline $4(60)$ & 79 & $37(47 \%)$ & $59(0.15 \%)$ \\
\hline $2(30)$ & 40 & $20(50 \%)$ & $25(0.06 \%)$ \\
\hline $2(30)$ & 40 & $29(72 \%)$ & $21(0.05 \%)$ \\
\hline $1(15)$ & 20 & $15(75 \%)$ & $15(0.04 \%)$ \\
\hline
\end{tabular}

Constants: beam energy, $E_{p}=14.7 \mathrm{MeV}$; beam current, $I=15 \mu \mathrm{A}$; target thickness, $t_{\text {target }}=0.64 \mathrm{~mm}$; theoretical specific activity, TSA $=40 \mathrm{Ci} \cdot \mu_{\mathrm{mol}}{ }^{-1}$. All activities have been decay-corrected to the end-of-bombardment time for each production.

The predicted activity produced from each cyclotron bombardment is given in Table 1 and was calculated using published empirical cross-section data for the ${ }^{\text {nat }} \mathrm{Y}(p, n)^{89} \mathrm{Zr}$ reaction [29-36] (see ESI) 
and the theoretical stopping ranges of protons in $\mathrm{Y}$ metal. The former data were accessed through the NNDC database [19] and the latter from calculations performed using the SRIM software [28]. By geometry, we estimated that $37 \%$ of the beam was lost on the lid of the target holder, instead of irradiating the exposed $\mathrm{Y}$ foil. The reaction rate $(R)$ was calculated, followed by the activity $(A)$, using the equation $A=R\left(1-e^{-\lambda t}\right)$ [52], where $\lambda$ is the decay constant for ${ }^{89} \mathrm{Zr}$. The predicted values were also used to evaluate the total activity in the automated module as a percentage, also shown in Table 1.

To confirm the radionuclidic purity of the solution in the product vial, gamma spectroscopy was performed. Typically, a short $(10 \mathrm{~m})$ scan of a diluted aliquot from the product vial was performed on the same day as each chemical separation, (see spectra in the ESI). For one production, a long (12 h) scan was performed after waiting for several half-lives ( $\sim 22$ days) of ${ }^{89} \mathrm{Zr}$ to allow it to decay relative to longer-lived potential radiocontaminants, making them easier to detect by gamma spectroscopy. This spectrum indicated a radionuclidic purity of ${ }^{89} \mathrm{Zr}$ equal to $99.998 \%$ of total activity $(99.95 \%$ of total atoms) and identified ${ }^{88} \mathrm{Zr}$ as the only radiocontaminant. Even though our recovery percentage was less than most other studies, our radionuclidic purity was on par with other publications, only one of which had a radionuclidic purity $<99 \%$. This is likely because of the minimal overlap of the excitation function for the ${ }^{\text {nat }} \mathrm{Y}(p, n){ }^{89} \mathrm{Zr}$ reaction with other ${ }^{\text {nat }} \mathrm{Y}(p, x)$ reactions, especially the ${ }^{\text {nat }} \mathrm{Y}(p, 2 n){ }^{88} \mathrm{Zr}$ reaction at these irradiation energies. For most productions of ${ }^{89} \mathrm{Zr}$ in this work, ESA was determined by DFO titration [23]. ESA accounts for the presence of any metal isotope (stable or radioactive) that can be chelated by the selected chelator, in this case, DFO. For each production, the results of the DFO titration were plotted and fit with a sigmoidal dose-response curve to produce an EC50 value (see ESI), which was used to calculate ESA in $\mathrm{mCi} \cdot \mu \mathrm{mol}^{-1}$. ESA was also expressed as a percentage of TSA, with absolute and relative ESA values shown in Table 1. Our results for ESA as a percentage of TSA were very low, although we expect when we produce and recover larger activities of ${ }^{89} \mathrm{Zr}$ this will improve. Only one other publication [23] reported ESA values, and our values were significantly less than their results, although typically our production activities were less as well. We did observe an improvement in ESA with increasing size of production batches, and we are saving samples to analyze for metal contaminants that would diminish the ESA. Elemental analysis will be performed on these samples by ion-coupled plasma mass spectrometry (ICP-MS).

\section{Conclusions}

In this work, we present the cyclotron production of ${ }^{89} \mathrm{Zr}$ using a biomedical cyclotron and the chemical separation of ${ }^{89} \mathrm{Zr}$ from a $\mathrm{Y}$ foil target using an automated module. This module dissolved the $\mathrm{Y}$ foil in acid and then separated the ${ }^{89} \mathrm{Zr}$ from $\mathrm{Y}$ using a hydroxamate resin column. Our methods reduced radiation dose to production personnel as the separation was carried out inside a lead hot cell, while the module was controlled by a laptop outside. The progress of the separation was monitored using radiation detectors in the module, and the final result for each production was a ${ }^{89} \mathrm{Zr}^{4+}$-oxalate solution, and this solution was characterized for recovery of activity, radionuclidic purity, and ESA. Our ${ }^{89} \mathrm{Zr}$ products had very high purity, similar to other published production methods. However, our productions had lower recovery percentages than other studies, possibly because we only collected one fraction from the column. Our ESA values were also lower than the only other paper that reported ESA, but that may improve with higher production activities. The procedures described in this work 
have been used for several months to routinely produce ${ }^{89} \mathrm{Zr}$ for users at our institution and for shipping to other institutions. Lessons learned from production of ${ }^{89} \mathrm{Zr}$ will be adapted for routine cyclotron production and chemical separation of other radiometals from solid targets.

\section{Acknowledgments}

The authors acknowledge G.G. Gaehle for advice in designing the automated module; W.H. Margenau and J.W. Linders for constructing certain components of the system; the Washington University School of Medicine Instrument Machine Shop and J.W. Linders for machining the $\mathrm{Nb}$ target holders; W.H. and P.M. Margenau for operation of the cyclotron; and O.F. Ikotun and B.V. Marquez for general advice on ${ }^{89} \mathrm{Zr}$ separation and chelation chemistries. The authors have no competing financial interests to disclose. A.L. Wooten was supported in part by a training grant from NIBIB/NIH (T32EB014855-01). This work was funded by the U.S. Department of Energy, Office of Science, Nuclear Physics Isotope Program under grant DESC0008657.

\section{Conflict of Interest}

The authors declare no conflict of interest.

\section{Electronic Supplementary Information}

Figure S1. Screen shots of cross-section data plots accessed via NNDC/BNL for reactions that can be induced in ${ }^{\text {nat }} \mathrm{Y}$ by low-energy protons. $(p, n)^{89 \mathrm{~g}} \mathrm{Zr}$ : blue, dark gray [29-36]; $(p, n)^{89 \mathrm{~m}} \mathrm{Zr}$ : dark yellow, light gray [36,53]; $(p, 2 n)^{88} \mathrm{Zr}$ : green [29,54-61]; $(p, n+p)^{88} \mathrm{Y}$ : red, light blue, maroon, violet [29-32,35,55-61]. Some data sets included the contribution from isomeric transition, and some did not.

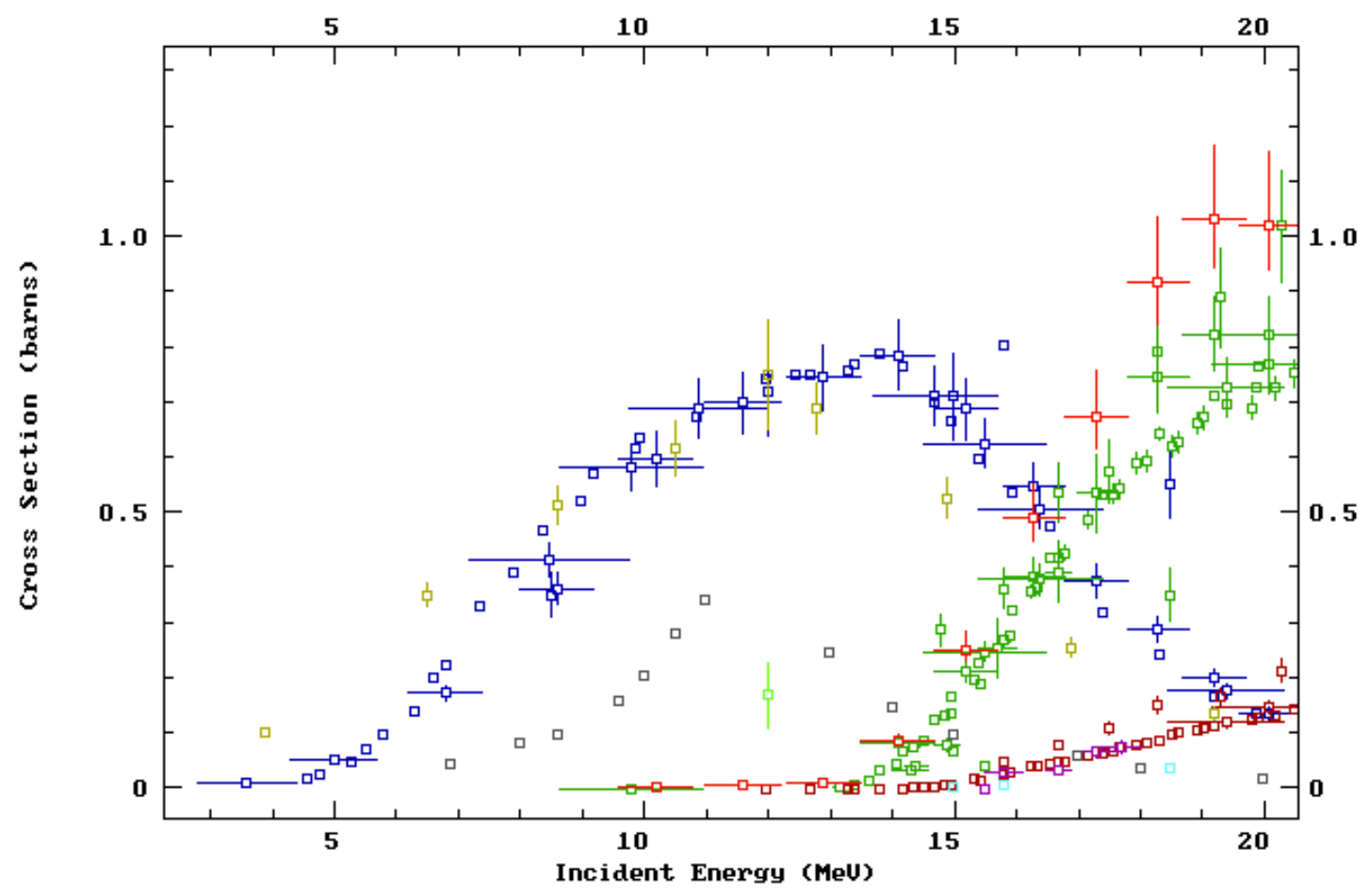


Table S1. Results from publications focused on ${ }^{89} \mathrm{Zr}$ production using the ${ }^{\text {nat }} \mathrm{Y}(p, n)$ reaction route, sorted by publication date from newest to oldest.

\begin{tabular}{|c|c|c|c|c|c|c|c|c|c|}
\hline & & $\begin{array}{l}\text { Y Foil } \\
\text { Thickness }\end{array}$ & $\begin{array}{l}\text { Bombardment } \\
\text { Parameters } \\
\end{array}$ & $\begin{array}{l}\text { Target Holder } \\
\text { Description }\end{array}$ & $\begin{array}{l}\text { Target Cooling } \\
\text { Description }\end{array}$ & $\begin{array}{l}\text { Activity/ } \\
(\mu \mathbf{A} \times \mathbf{h})\end{array}$ & \% Recovery & $\begin{array}{l}\text { Radionuclidic } \\
\text { Purity }\end{array}$ & ESA \\
\hline & & $\mathrm{mm}$ & $\mu \mathrm{A} \times \mathrm{h}$ & & & $\begin{array}{l}\mathrm{mCi} / \\
(\mathrm{uA} \times \mathrm{h})\end{array}$ & & $\begin{array}{l}\% \text { of total } \\
\text { activity }\end{array}$ & $\begin{array}{l}\mathrm{mCi} \cdot \mu \mathrm{mol}^{-1} \\
(\% \text { of TSA })\end{array}$ \\
\hline This Work & 2013 & 0.64 & $15 \times 4^{\S}=60$ & Machined $\mathrm{Nb}$ & $\begin{array}{l}\text { Chilled water }\left(2.2^{\circ} \mathrm{C}\right) \text {; } \\
\text { He jet (beam side) }\end{array}$ & $3.67-15$ & $93 \%{ }^{\dagger}$ & $99.998 \%$ & $\begin{array}{l}5-353 \\
(0.01 \%-0.88 \%) \\
\end{array}$ \\
\hline Walther, et al. [20] & 2011 & 0.15 & $12 \times 2=24$ & Aluminum & $\begin{array}{l}\text { Chilled water; } \\
\text { He jet (beam side) }\end{array}$ & 0.338 & $97.5 \%$ & $>95 \%$ & - \\
\hline Dutta, et al. [21] & 2009 & 0.009 & $0.54 \times 2.3=1.3$ & - & - & - & - & - & - \\
\hline Kandil, et al. [22] & 2007 & $\begin{array}{l}13 \\
\left(\mathrm{Y}_{2} \mathrm{O}_{3} \text { pellet diam. }\right)\end{array}$ & $2 \times 5=10$ & $\begin{array}{l}\text { Covered with } \\
\text { Al foil }\end{array}$ & Chilled water $\left(13^{\circ} \mathrm{C}\right)$ & 0.754 & $97.5 \%$ & $99.9 \%$ & - \\
\hline Holland, et al. [23] & 2005 & 0.10 & $15 \times 5=75$ & $10^{\circ}$ slant & Chilled water $\left(25^{\circ} \mathrm{C}\right)$ & 1.52 & $99.5 \%$ & $99.9 \%$ & $\begin{array}{l}470-1195 \\
(1.2 \%-3.0 \%)\end{array}$ \\
\hline Verel, et al. [24] & 2003 & $\begin{array}{l}0.035 \\
\text { (sputtered) }\end{array}$ & $80 \times 3=240$ & onto $\mathrm{Cu}$ plate & - & 0.002 & $97 \%$ & $99.9 \%$ & - \\
\hline Meijs, et al. [25] & 1994 & $\begin{array}{l}0.025 \\
\text { (sputtered) }\end{array}$ & $100 \times 1=100$ & onto $\mathrm{Cu}$ plate & - & 0.069 & $98 \%$ & - & - \\
\hline DeJesus and Nickles [26] & 1990 & 0.127 and 0.6 & $10 \times 2=20$ & - & Chilled water & 43 and 100 & $95 \%$ & $87 \%$ & - \\
\hline Link, et al. [27] & 1986 & - & $10 \times 0.66=6.7$ & - & - & 10.51 & $25 \%-80 \%$ & $99 \%$ & - \\
\hline
\end{tabular}

ESA: effective specific activity TSA: theoretical specific activity, $\left(40 \mathrm{Ci} \cdot \mu \mathrm{mol}^{-1}\right.$ for $\left.{ }^{89} \mathrm{Zr}\right)$. We selected the highest recovery from the productions that are presented in this table.

$\S$ longest bombardment; ${ }^{\dagger}$ average recovery; ${ }^{*}$ total recovery from multiple fractions. 
Figure S2. Results of a Monte Carlo simulation [28] of $14.7 \mathrm{MeV}$ protons $(N=1,000)$, travelling from left to right, as they pass through a $0.64 \mathrm{~mm}$ thick $\mathrm{Y}$ foil (Layer 1), and stopping within $0.3 \mathrm{~mm}$ after entering the $\mathrm{Nb}$ base of the target holder (Layer 2). The entire thickness of the base $(4.83 \mathrm{~mm})$ is not shown. This diagram assumes that the $\mathrm{Y}$ foil is perfectly in contact with the $\mathrm{Nb}$ base.

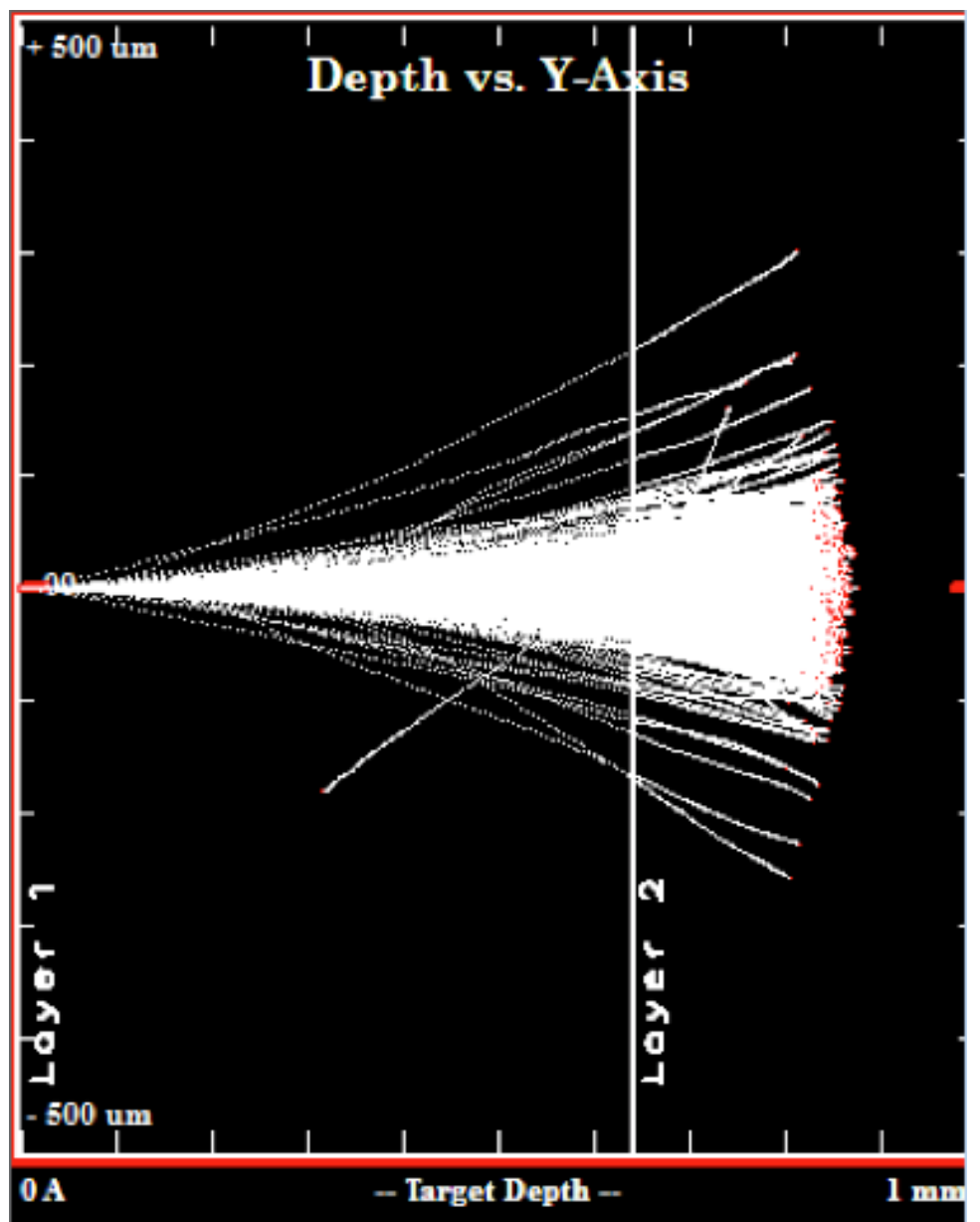


Table S2. Relevant characteristics for reactions that can be induced by $14.7 \mathrm{MeV}$ protons in ${ }^{\text {nat }}$ Y foil target.

\begin{tabular}{|c|c|c|c|c|c|c|}
\hline \multirow[t]{2}{*}{ Reaction } & Product & Half-Life & Decay Mode(s) & Daughter (Yield\%) & $\begin{array}{c}\text { Gamma Ray Energy } \\
\text { and Intensitv }\end{array}$ & Radionuclidic Purity \\
\hline & & $t_{1 / 2}$ & & & $\mathbf{E}_{\gamma} \mathrm{keV}(\mathbf{y} \%)$ & $\begin{array}{c}\% \text { of total activity } \\
\text { (\% of atoms) }\end{array}$ \\
\hline \multirow[t]{3}{*}{$(p, n)$} & ${ }^{89} \mathrm{Zr}$ & 3.3 days & $100 \% \varepsilon\left(77.3 \% \mathrm{EC}, 22.7 \% \beta^{+}\right)$ & ${ }^{89} \mathrm{Y}(100 \%$, stable $)$ & $909(99.0 \%)$ & $99.998 \%$ (99.95\%) \\
\hline & & & & & $1713(0.7 \%)$ & \\
\hline & & & & & $1745(0.1 \%)$ & \\
\hline \multirow[t]{3}{*}{$(p, n)$} & ${ }^{89 \mathrm{~m}} \mathrm{Zr}$ & $4.2 \mathrm{~m}$ & $93.8 \% \mathrm{IT}, 6.2 \% \varepsilon\left(4.7 \% \mathrm{EC}, 1.5 \% \beta^{+}\right)$ & ${ }^{89} \operatorname{Zr}(93.8 \%),{ }^{89} \mathrm{Y}(6.2 \%$, stable $)$ & $588(89.6 \%)$ & Not Observed \\
\hline & & & & & $1507(6.1 \%)$ & \\
\hline & & & & & - & \\
\hline \multirow[t]{3}{*}{$(p, 2 n)$} & ${ }^{88} \mathrm{Zr}$ & 83.4 days & $100 \% \varepsilon(100 \% \mathrm{EC})$ & ${ }^{88} \mathrm{Y}(100 \%)$ & $393(97.3 \%)$ & $0.002 \%(0.05 \%)$ \\
\hline & & & & & - & \\
\hline & & & & & - & \\
\hline \multirow[t]{4}{*}{$(p, p n)$} & ${ }^{88} \mathrm{Y}$ & 106.6 days & $100 \% \varepsilon\left(100 \% \beta^{+}\right)$ & ${ }^{88} \operatorname{Sr}(100 \%$, stable $)$ & $1836(99.2 \%)$ & Not Observed \\
\hline & & & & & 898 (93.7\%) & \\
\hline & & & & & $2734(0.7 \%)$ & \\
\hline & & & & & TOTAL $=$ & $100.00 \%$ \\
\hline
\end{tabular}

${ }^{89} \mathrm{Y}$ is $100 \%$ naturally abundant. Isomers were excluded if they had a half-life less than $1 \mathrm{~s}$ with exactly $100 \%$ decay by isomeric transition. Yield is the percentage of all parent nuclei that decay to the specified daughter isotope. The decay of all radioactive daughter isotopes were described elsewhere. For each isotope, this table displays the three signature gamma rays (if applicable) with the highest intensities that are at least $0.1 \%$. Radionuclidic purity was based on a single $12 \mathrm{~h}$ scan of the product solution from an ${ }^{89} \mathrm{Zr}$ production, 21 days after its cyclotron bombardment. All data were accessed via BNL/NNDC [19]. 
Table S3. Summary of results from productions of ${ }^{89} \mathrm{Zr}$ (sorted highest to lowest by recovery percentages).

\begin{tabular}{|c|c|c|c|c|}
\hline $\begin{array}{l}\text { Product Vial } \\
\text { mCi (\%) }\end{array}$ & $\begin{array}{l}\text { Waste Vial } \\
\text { mCi (\%) } \\
\end{array}$ & $\begin{array}{l}\text { Column } \\
\text { mCi (\%) }\end{array}$ & $\begin{array}{c}\text { Dissolution } \\
\text { Vessel } \\
\text { mCi (\%) } \\
\end{array}$ & $\begin{array}{c}\text { Estimated } \\
\text { Total Activity } \\
\text { mCi } \\
\end{array}$ \\
\hline $14.2(97 \%)$ & $0.1(0.5 \%)$ & $0.0(0 \%)$ & $0.3(2 \%)$ & 14.6 \\
\hline $14.6(93 \%)$ & $0.4(2.5 \%)$ & $0.4(2 \%)$ & $0.4(2 \%)$ & 15.8 \\
\hline $13.7(84 \%)$ & $0.0(0.0 \%)$ & $2.3(14 \%)$ & $0.3(2 \%)$ & 16.3 \\
\hline $24.7(84 \%)$ & $3.8(12.9 \%)$ & $0.1(0 \%)$ & $0.9(3 \%)$ & 29.4 \\
\hline $23.3(82 \%)$ & $0.1(0.3 \%)$ & $3.6(13 \%)$ & $1.6(5 \%)$ & 28.6 \\
\hline $16.0(79 \%)$ & $1.4(6.9 \%)$ & $2.6(13 \%)$ & $0.2(1 \%)$ & 20.1 \\
\hline $48.1(78 \%)$ & $0.2(0.2 \%)$ & $7.7(12 \%)$ & $6.0(10 \%)$ & 62.0 \\
\hline $20.2(74 \%)$ & $0.1(0.3 \%)$ & $6.5(24 \%)$ & $0.5(2 \%)$ & 27.3 \\
\hline $21.5(71 \%)$ & $0.0(0.1 \%)$ & $7.4(24 \%)$ & $1.4(5 \%)$ & 30.4 \\
\hline $9.1(61 \%)$ & $0.2(1.2 \%)$ & $5.5(36 \%)$ & $0.3(2 \%)$ & 15.0 \\
\hline $16.4(56 \%)$ & $0.1(0.5 \%)$ & $12.7(43 \%)$ & $0.3(1 \%)$ & 29.6 \\
\hline $15.1(50 \%)$ & $0.1(0.3 \%)$ & $14.6(48 \%)$ & $0.4(1 \%)$ & 30.1 \\
\hline $16.4(44 \%)$ & $13.8(37 \%)$ & $4.5(12 \%)$ & $2.5(7 \%)$ & 37.2 \\
\hline
\end{tabular}

Percentages represent the percent of total activity.

Figure S3. Gamma spectra of diluted aliquots from the product vial from two different productions. (A) A $10 \mathrm{~m}$ scan taken on the same day as chemical separation, and (B) a $12 \mathrm{~h}$ scan taken 22 days after the chemical separation. $E_{\gamma}$ : gamma-ray energy; a.u.: arbitrary units. Spectra were zoomed in on $0 \leq E_{\gamma} \leq 2,000 \mathrm{keV}$.

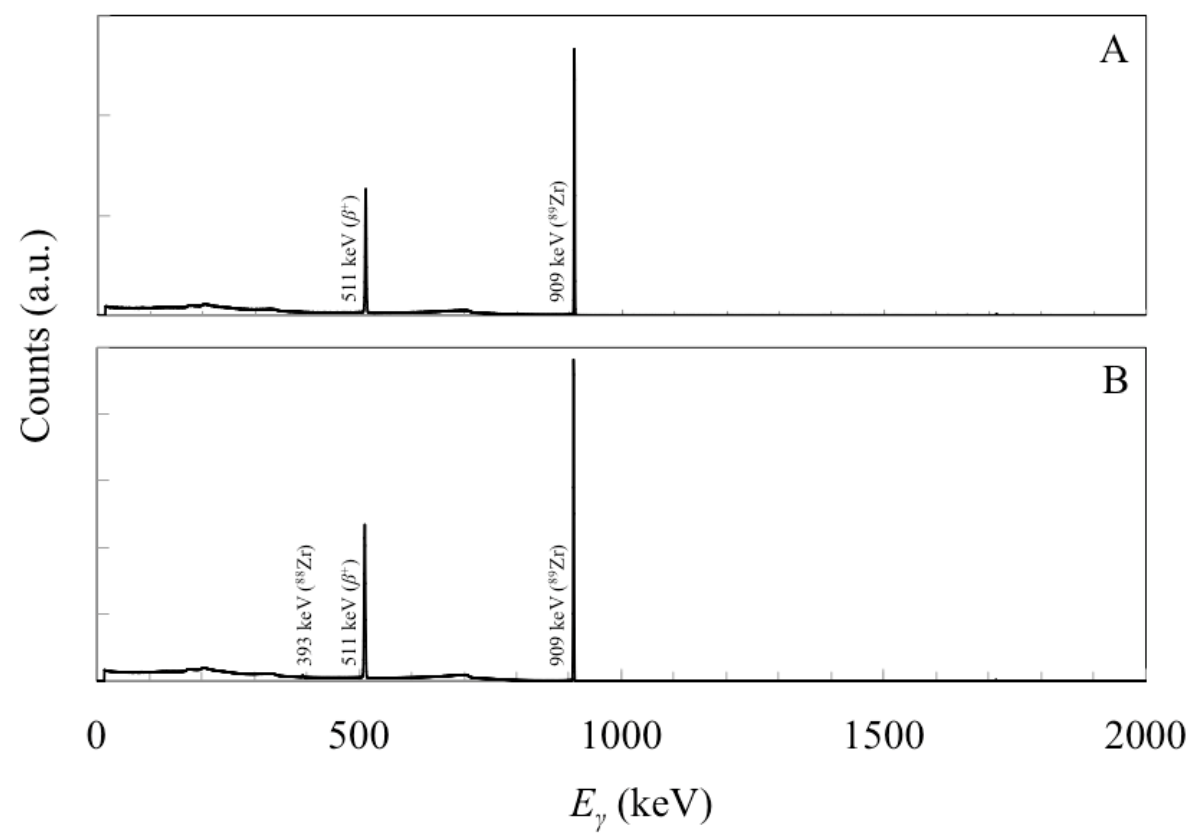


Figure S4. DFO- ${ }^{89} \mathrm{Zr}$ titration curve that resulted in an effective specific activity of $63 \mathrm{mCi} \cdot \mu \mathrm{mol}^{-1}$ for a selected ${ }^{89} \mathrm{Zr}$ production. Fit: sigmoidal dose-response curve.

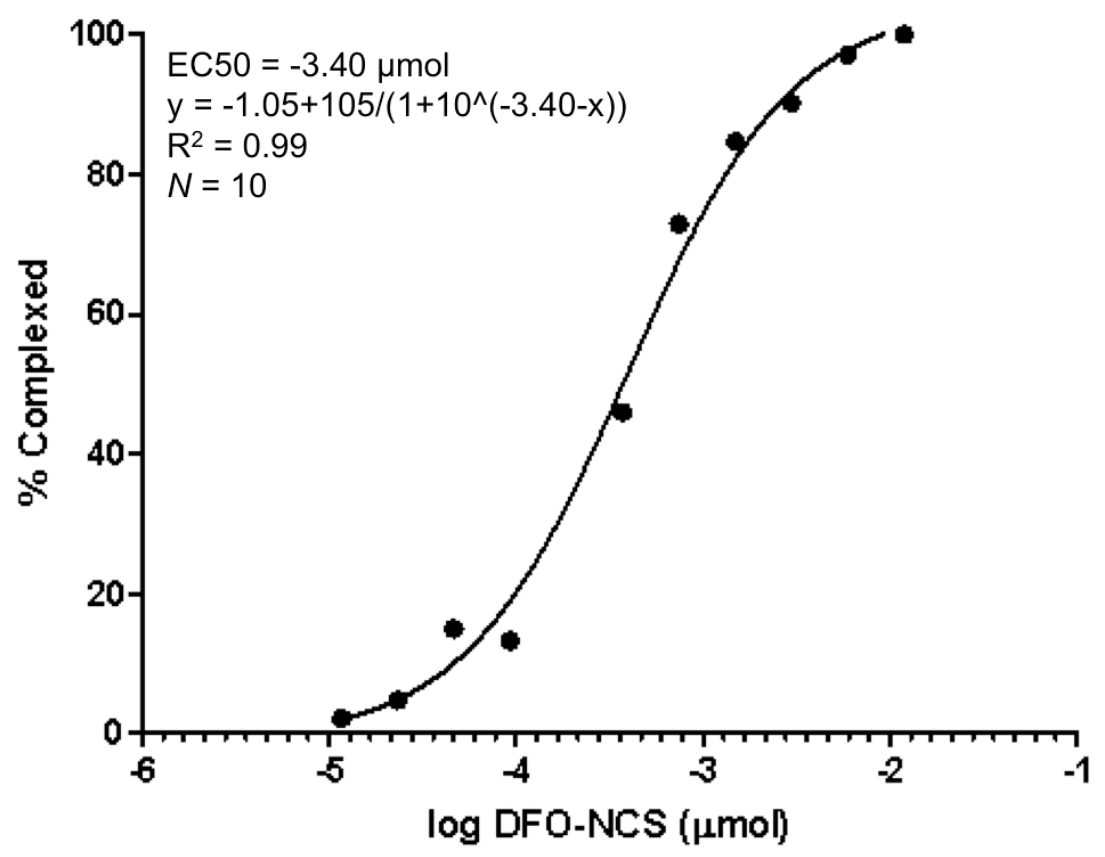

\section{References}

1. Ikotun, O.F.; Lapi, S.E. The rise of metal radionuclides in medical imaging: Copper-64, Zirconium-89 and Yttrium-86. Future Med. Chem. 2011, 3, 599-621.

2. Wadas, T.J.; Wong, E.H.; Weisman, G.R.; Anderson, C.J. Coordinating radiometals of Copper, Gallium, Indium, Yttrium, and Zirconium for PET and SPECT imaging of disease. Chem. Rev. 2010, 110, 2858-2902.

3. Holland, J.P.; Williamson, M.J.; Lewis, J.S. Unconventional nuclides for radiopharmaceuticals. Mol. Imag. 2010, 9, 1-20.

4. Nayak, T.K.; Brechbiel, M.W. Radioimmunoimaging with longer-lived positron-emitting radionuclides: Potentials and challenges. Bioconj. Chem. 2009, 20, 825-841.

5. Anderson, C.J.; Welch, M.J. Radiometal-labeled agents (non-technetium) for diagnostic imaging. Chem. Rev. 1999, 99, 2219-2234.

6. PubMed Online Database. Available online: http://www.ncbi.nlm.nih.gov/pubmed/ (accessed on 3 May 2013).

7. Vugts, D.J.; Visser, G.W.M.; van Dongen, G.A.M.S. ${ }^{89}$ Zr-PET radiochemistry in the development and application of therapeutic monoclonal antibodies and other biologicals. Curr. Top. Med. Chem. 2013, 13, 446-457.

8. Deri, M.A.; Zeglis, B.M.; Francesconi, L.C.; Lewis, J.S. PET imaging with ${ }^{89}$ Zr: From radiochemistry to the clinic. Nucl. Med. Biol. 2013, 40, 3-14.

9. Severin, G.W.; Engle, J.W.; Barnhart, T.E.; Nickles, R.J. ${ }^{89} \mathrm{Zr}$ Radiochemistry for positron emission tomography. Med. Chem. 2011, 7, 389-394.

10. Zhang, Y.; Hong, H.; Cai, W. PET tracers based on Zirconium-89. Curr. Radiopharm. 2011, 4, $131-139$. 
11. McCabe, K.E.; Wu, A.M. Positive progress in immunoPET-Not just a coincidence. Cancer Biother. Radiopharm. 2010, 25, 253-261.

12. Van Dongen, G.A.M.S.; Vosjan, M.J.W.D. Immuno-positron emission tomography: Shedding light on clinical antibody therapy. Can. Biother. Radiopharm. 2010, 25, 375-385.

13. Van Dongen, G.A.M.S.; Visser, G.W.M.; Lub-de Hooge, M.N.; de Vries, E.G.; Perk, L.R. Immuno-PET: A navigator in monoclonal antibody development and applications. Oncologist 2007, 12, 1379-1389.

14. Verel, I.; Visser, G.W.M.; van Dongen, G.A.M.S. The promise of immuno-PET in radioimmunotherapy. $J$. Nucl. Med. 2005, 46, 164s-171s.

15. Disselhorst, J.A.; Brom, M.; Laverman, P.; Slump, C.H.; Boerman, O.C.; Oyen, W.J.; Gotthardt, M.; Visser, E.P. Image-quality assessment for several positron emitters using the nema nu 4-2008 standards in the siemens inveon small-animal pet scanner. J. Nucl. Med. 2010, 51, $610-617$.

16. Smith, D.S.; Stabin, M.G. Exposure rate constants and lead shielding values for over 1,100 radionuclides. Health Phys. 2012, 102, 271-291.

17. Meijs, W.E.; Herscheid, J.D.M.; Haisma, H.J.; Pinedo, H.M. Evaluation of desferal as a bifunctional chelating agent for labeling antibodies with Zr-89. Appl. Radiat. Isot. 1992, 43, 1443-1447.

18. Kasbollah, A.; Eu, P.; Cowell, S.; Deb, P. Review on production of ${ }^{89} \mathrm{Zr}$ in a medical cyclotron for PET radiopharmaceuticals. J. Nucl. Med. Technol. 2013, 41, 35-41.

19. National Nuclear Data Center (NNDC). Available online: http://www.nndc.bnl.gov (accessed on 4 July 2013).

20. Walther, M.; Gebhardt, P.; Grosse-Gehling, P.; Würbach, L.; Irmler, I.; Preusche, S.; Khalid, M.; Opfermann, T.; Kamradt, T.; Steinbach, J.; et al. Implementation of ${ }^{89} \mathrm{Zr}$ production and in vivo imaging of B-cells in mice with ${ }^{89} \mathrm{Zr}$-labeled anti-B-cell antibodies by small animal PET/CT. Appl. Radiat. Isot. 2011, 69, 852-857.

21. Dutta, B.; Maiti, M.; Lahiri, S. Production of ${ }^{88,89} \mathrm{Zr}$ by proton induced activation of ${ }^{\text {nat }} \mathrm{Y}$ and separation by SLX and LLX. J. Radioanal. Nucl. Chem. 2009, 281, 663-667.

22. Kandil, S.A.; Scholten, B.; Saleh, Z.A.; Youssef, A.M.; Qaim, S.M.; Coenen, H.H. A comparative study on the separation of radiozirconium via ion-exchange and solvent extraction techniques, with particular reference to the production of ${ }^{88} \mathrm{Zr}$ and ${ }^{89} \mathrm{Zr}$ in proton induced reactions on yttrium. J. Radioanal. Nucl. Chem. 2007, 274, 45-52.

23. Holland, J.P.; Sheh, Y.; Lewis, J.S. Standardized methods for the production of high specific-activity zirconium-89. Nucl. Med. Biol. 2005, 36, 729-739.

24. Verel, I.; Visser, G.W.M.; Boellaard, R.; Stigter-van Walsum, M.; Snow, G.B.; van Dongen, G.A. ${ }^{89} \mathrm{Zr}$ immuno-PET: Comprehensive procedures for the production of ${ }^{89} \mathrm{Zr}$-labeled monoclonal antibodies. J. Nucl. Med. 2003, 44, 1271-1281.

25. Meijs, W.E.; Herscheid, J.D.M.; Haisma, H.J.; van Langevelde, F.; Wijbrandts, R.; van Leuffen, P.J.; Mooy, R.; Pinedo, H.M. Production of highly pure no-carrier added ${ }^{89} \mathrm{Zr}$ for the labelling of antibodies with a positron emitter. Appl. Radiat. Isot. 1994, 45, 1143-1147.

26. DeJesus, O.T.; Nickles, R.J. Production and purification of $89 \mathrm{Zr}$, a potential PET antibody label. Appl. Radiat. Isot. 1990, 41, 789-790. 
27. Link, J.M.; Krohn, K.A.; Eary, J.F.; Kishore, R.; Lewellen, T.K.; Johnson, M.W.; Badger, C.C.; Richter, K.Y.; Nelp, W.B. ${ }^{89} \mathrm{Zr}$ for antibody labeling and positron emission tomography. J. Label. Compd. Radiopharm. 1986, 23, 1297-1298.

28. The Stopping and Range of Ions in Matter, version SRIM-2008; SRIM Company: Chester, MD, USA, 2008.

29. Khandaker, M.U.; Kim, K.; Lee, M.-W.; Kim, K.-S.; Kim, G.; Otuka, N. Investigations of ${ }^{89} \mathrm{Y}(\mathrm{p}, \mathrm{x}){ }^{86,88,89 \mathrm{~g}} \mathrm{Zr},{ }^{86 \mathrm{~m}+\mathrm{g}, 87 \mathrm{~g}, 87 \mathrm{~m}, 88 \mathrm{~g}} \mathrm{Y},{ }^{85 \mathrm{~g}} \mathrm{Sr}$, and ${ }^{84 \mathrm{~g}} \mathrm{Rb}$ nuclear processes up to $42 \mathrm{MeV}$. Nucl. Instr. Meth. Phys. Res. B 2012, 271, 72-81.

30. Uddin, M.S.; Hagiwara, M.; Baba, M. Experimental studies on excitation functions of the proton-induced activation reactions on yttrium. Appl. Radiat. Isot. 2005, 63, 367-374.

31. Michel, R.; Bodemann, R.; Busemann, H.; Daunke, R.; Gloris, M.; Lange, H.-J.; Klug, B.; Krins, A.; Leya, I.; Lüpke, M.; et al. Cross sections for the production of residual nuclides by low- and medium-energy protons from the target elements $\mathrm{C}, \mathrm{N}, \mathrm{O}, \mathrm{Mg}, \mathrm{Al}, \mathrm{Si}, \mathrm{Ca}, \mathrm{Ti}, \mathrm{V}, \mathrm{Mn}, \mathrm{Fe}$, $\mathrm{Co}, \mathrm{Ni}, \mathrm{Cu}, \mathrm{Sr}, \mathrm{Y}, \mathrm{Zr}, \mathrm{Nb}, \mathrm{Ba}$ and Au. Nucl. Instr. Meth. Phys. Res. B 1997, 129, 153-193.

32. Mustafa, M.G.; West, H.I., Jr.; O’Brien, H.; Lanier, R.G.; Benhamou, M.; Tamura, T. Measurements and a direct-reaction-plus-Hauser-Feshbach analysis of ${ }^{89} \mathrm{Y}(p, n)^{89} \mathrm{Zr}$, ${ }^{89} \mathrm{Y}(p, 2 n){ }^{88}[\mathrm{sic}]$, and ${ }^{89} \mathrm{Y}(p, p n){ }^{88} \mathrm{Y}$ reactions up to $40 \mathrm{MeV}$. Phys. Rev. C 1988, 38, 1624-1637.

33. Birattari, C.; Gadioli, E.; Gadioli Erba, E. Pre-equilibrium processes in $(\mathrm{P}, \mathrm{N})$ reactions. Nucl. Phys. A 1973, 201, 579-592.

34. Church, L.B.; Caretto, A.A., Jr. Study of $(p, x n)$ Reactions at $400 \mathrm{MeV}$. Phys. Rev. 1969, 178, 1732-1742.

35. Saha, G.B.; Porile, N.T.; Yaffe, L. $(\mathrm{p}, \mathrm{xn})$ and (p,pxn) reactions of Yttrium-89 with 5-85 MeV protons. Phys. Rev. 1966, 144, 962-971.

36. Blosser, H.G.; Handley, T.H. Survey of (P,N) reactions at 12 MeV. Phys. Rev. 1955, 100, 1340-1344.

37. Lahiri, S.; Mukhopadhyay, B.; Das, N.A. Simultaneous production of ${ }^{89} \mathrm{Zr}$ and ${ }^{90,91 \mathrm{~m}, 92 \mathrm{~m}} \mathrm{Nb}$ in alpha-particle activated yttrium and their separation by HDEHP. Appl. Radiat. Isot. 1997, 48, 883-886.

38. Zweit, J.; Downey, S.; Sharma, H.L. Production of no-carrier-added zirconium-89 for positron emission tomography. Appl. Radiat. Isot. 1991, 42, 199-201.

39. Herscheid, J.D.M.; Vos, C.M.; Hoekstra, A. Manganese-52m for direct application: A new ${ }^{52} \mathrm{Fe} /{ }^{52 \mathrm{~m}} \mathrm{Mn}$ generator based on a hydroxamate resin. Int. J. Appl. Radiat. Isot. 1983, 34, 883-886.

40. Fadeeva, V.I.; Tikhomirova, T.I.; Yuferova, I.B.; Kudryavtsev, G.V. Preparation, properties and analytical applications of silica with chemically grafted hydroxamic acid groups. Anal. Chim. Acta 1989, 219, 201.

41. Kume, M.; Carey, P.C.; Gaehle, G.G.; Madrid, E.; Voller, T.; Margenau, W.; Welch, M.J.; Lapi, S.E. A semi-automated system for the routine production of copper-64. Appl. Radiat. Isot. 2012, 70, 1803-1806.

42. Burke, P.; Golovko, O.; Clark, J.C.; Aigbirhio, F.I. An automated method for regular productions of copper-64 for PET radiopharmaceuticals. Inorg. Chim. Acta 2010, 363, 1316-1319. 
43. Matarrese, M.; Bedeschi, P.; Scardaoni, R.; Sudati, F.; Savi, A.; Pepe, A.; Masiello, V.; Todde, S.; Gianolli, L.; Messa, C.; et al. Automated production of copper radioisotopes and preparation of high specific activity $\left[{ }^{64} \mathrm{Cu}\right] \mathrm{Cu}-\mathrm{ATSM}$ for PET studies. Appl. Radiat. Isot. 2010, 68, 5-13.

44. Welch, M.J.; Tang, L.L.W.; Gaehle, G.G.; Lewis, J.S. Automated separation, purification and labeling systems for ${ }^{60} \mathrm{Cu},{ }^{61} \mathrm{Cu}$ and ${ }^{64} \mathrm{Cu}$ Radionuclides and Recovery Thereof. U.S. Patent No.: US 2006/0004491 A1, 5 January 2006.

45. Nagatsu, K.; Fukada, M.; Minegishi, K.; Suzuki, H.; Fukumura, T.; Yamazaki, H.; Suzuki, K. Fully automated production of iodine-124 using a vertical beam. Appl. Radiat. Isot. 2011, 69, 146-157.

46. Chattopadhyay, S.; Barua, L.; De, A.; Das, S.S.; Kuniyil, R.; Bhaskar, P.; Pal, S.S.; Sarkar, S.K.; Das, M.K. A computerized compact module for separation of ${ }^{99 \mathrm{~m}}$ Tc-radionuclide from molybdenum. Appl. Radiat. Isot. 2012, 70, 2631-2637.

47. Park, L.S.; Szajek, L.P.; Wong, K.J.; Plascjak, P.S.; Garmestani, K.; Googins, S.; Eckelman, W.C.; Carrasquillo, J.A.; Paik, C.H. Semi-automated ${ }^{86} \mathrm{Y}$ purification using a three-column system. Nucl. Med. Biol. 2004, 31, 297-301.

48. Wooten, A.L.; Schweitzer, G.D.; Lawrence, L.A.; Madrid, E.; Lapi, S.E. An automated system for production of ${ }^{89} \mathrm{Zr}$. AIP Conf. Proc. 2012, 1509, 201-205.

49. Siikanen, J.; Peterson, M.; Tran, T.A.; Roos, P.; Ohlsson, T.; Sandell, A. A peristaltic pump driven ${ }^{89} \mathrm{Zr}$ separation module. AIP Conf. Proc. 2012, 1509, 206-210.

50. Greenwood, N.N.; Earnshaw, A. Chemistry of the Elements; Butterworth-Heinemann: Oxford, UK, 1997; p. 979.

51. Edraw Max, version 6.8.1.; EdrawSoft Company: Hong Kong, 2013.

52. Ehmann, W.D.; Vance, D.E. Radiochemistry and Nuclear Methods of Analysis; Wiley: New York, NY, USA, 1991; pp. 92-93, 141-142.

53. Gritsyna, V.T.; Klyucharev, A.P.; Remaev, V.V.; Reshetova, L.N. Ratio of the cross sections for the production of the isomer and ground states of nuclei in the $(p, n)$ reaction at the energies from the threshold to $20 \mathrm{MeV}$. Sov. Phys. JETP 1963, 17, 1186-1189.

54. Steyn, G.F.; Vermeulen, C.; Szelecsenyi, F.; Kovacs, Z.; Suzuki, K.; Fukumura, T.; Nagatsu, K. Excitation functions of proton induced reactions on ${ }^{89} \mathrm{Y}$ and ${ }^{93} \mathrm{Nb}$ with special emphasis on the production of selected radio-zirconiums. J. Kor. Phys. Soc. 2011, 59, 1991-1994.

55. Omara, H.M.; Hassan, K.F.; Kandil, S.A.; Hegazy, F.E.; Saleh, Z.A. Proton induced reactions on ${ }^{89} \mathrm{Y}$ with particular reference to the production of the medically interesting radionuclide ${ }^{89} \mathrm{Zr}$. Radiochim. Acta 2009, 97, 467-471.

56. Tarkanyi, F.; Ditroi, F.; Takacs, S.; Csikai, J.; Mahunka, I.; Uddin, M.S.; Hagiwara, M.; Baba, M.; Ido, T.; Hermanne, A.; et al. Excitation functions for production of ${ }^{88} \mathrm{Zr}$ and ${ }^{88} \mathrm{Y}$ by proton and deuteron irradiation of Mo, Nb, Zr and Y. AIP Conf. Proc. 2005, 769, 1658-1661.

57. Zhao, W.; Shen, Q.; Lu, H.; Yu, W. Investigation of Y-89(p,n)Zr-89, Y-89(p,2n)Zr-88 and Y-89(p,pn)Y-88 reactions up to $22 \mathrm{MeV}$. Chin. J. Nucl. Phys. (Beijing) 1992, 14, 7.

58. Levkovskij, V.N. Middle Mass Nuclides $(\mathrm{A}=40-100)$ Activation Cross-sections by Medium Energy $(\mathrm{E}=10-50 \mathrm{MeV})$ Protons and Alpha Particles (Experiment and Systematics). Inter. Vesi. (Moscow) 1991. 
59. Regnier, S.; Lavielle, B.; Simonoff, M.; Simonoff, G.N. Nuclear reactions in Rb, Sr, Y and Zr targets. Phys. Rev. C 1982, 26, 931-943.

60. Levenberg, I.; Pokrovsky, V.; Tarasova, L.; Simonoff, G.N. Reactions (p,pn), (p,2n) and (p,n) on Y-89 Induced by high-energy protons. Nucl. Phys. 1966, 81, 81-87.

61. Caretto, A.A.; Wiig, E.O. Interaction of Yttrium with protons of energy between 60 and $240 \mathrm{MeV}$. Phys. Rev. 1959, 115, 1238-1242.

(C) 2013 by the authors; licensee MDPI, Basel, Switzerland. This article is an open access article distributed under the terms and conditions of the Creative Commons Attribution license (http://creativecommons.org/licenses/by/3.0/). 